Article

\title{
Cell Penetrating Peptide as a High Safety Anti-Inflammation Ingredient for Cosmetic Applications
}

\author{
Tse-Kai Fu ${ }^{1,2,+}$, Ping-Hsueh Kuo ${ }^{1,+}$, Yen-Chang Lu ${ }^{1}$, Hsing-Ni Lin ${ }^{1}$, Lily Hui-Ching Wang ${ }^{1,3}$, \\ Yu-Chun Lin ${ }^{4}$, Yu-Chen Kao ${ }^{4}$, Huey-Min Lai ${ }^{4, *}$ and Margaret Dah-Tsyr Chang ${ }^{1,5, *}$ \\ 1 Institute of Molecular and Cellular Biology, National Tsing Hua University, Hsinchu 30013, Taiwan; \\ gn00042366@gmail.com (T.-K.F.); s9980584nthu@gapp.nthu.edu.tw (P.-H.K.); \\ johnnylu0629@gmail.com (Y.-C.L.); sisnin66@gamil.com (H.-N.L.); lilywang@life.nthu.edu.tw (L.H.-C.W.) \\ 2 Research and Development Department, Simpson Biotech Co., Ltd., Taoyuan 333, Taiwan \\ 3 Department of Medical Science, National Tsing Hua University, Hsinchu 30013, Taiwan \\ 4 Industrial Technology Research Institute, Hsinchu 30011, Taiwan; YuChunLin@itri.org.tw (Y.-C.L.); \\ YCKao@itri.org.tw (Y.-C.K.) \\ 5 Department of Life Science, National Tsing Hua University, Hsinchu 30013, Taiwan \\ * Correspondence: HMLai@itri.org.tw (H.-M.L.); dtchang@life.nthu.edu.tw (M.D.-T.C.); \\ Tel.: +886-3-573-2765 (H.-M.L.); +886-3-574-2767 (M.D.-T.C.) \\ + These authors contributed equally to this work.
}

Received: 28 November 2019; Accepted: 4 January 2020; Published: 7 January 2020 updates

\begin{abstract}
Cosmeceutical peptides have become an important topic in recent decades in both academic and industrial fields. Many natural or synthetic peptides with different biological functions including anti-ageing, anti-oxidation, anti-infection and anti-pigmentation have been developed and commercialized. Current cosmeceutical peptides have already satisfied most market demand, remaining: "cargos carrying skin penetrating peptide with high safety" still an un-met need. To this aim, a cell-penetrating peptide, $\mathrm{CPP}_{\mathrm{AIF}}$, which efficiently transported cargos into epithelial cells was exanimated. $\mathrm{CPP}_{\mathrm{AIF}}$ was evaluated with cell model and 3D skin model following OECD guidelines without using animal models. As a highly stable peptide, $\mathrm{CPP}_{\mathrm{AIF}}$ neither irritated nor sensitized skin, also did not disrupt skin barrier. In addition, such high safety peptide had anti-inflammation activity without allergic effect. Moreover, cargo carrying activity of $\mathrm{CPP}_{\mathrm{AIF}}$ was assayed using $\mathrm{HaCaT}$ cell model and rapid $\mathrm{CPP}_{\text {AIF }}$ penetration was observed within $30 \mathrm{~min}$. Finally, $\mathrm{CPP}_{\text {AIF }}$ possessed transepidermal activity in water in oil formulation without disruption of skin barrier. All evidences indicated that $\mathrm{CPP}_{\mathrm{AIF}}$ was an ideal choice for skin penetrating and its anti-inflammatory activity could improve skin condition, which made $\mathrm{CPP}_{\mathrm{AIF}}$ suitable and attractive for novel cosmeceutical product development.
\end{abstract}

Keywords: cell-penetrating peptides; cosmeceutical peptides; anti-inflammation

\section{Introduction}

Peptides, polymers composed of amino acids, are known to possess versatile biological functions such as promoting cell proliferation, migration, inflammation/anti-inflammation, angiogenesis, and melanogenesis [1], which causes numerous physiological procedures in human body [2]. The first synthetic peptide incorporated into skin care products in the late 80s was copper glycine-histidine-lysine (Cu-GHK) generated by Pickard in 1973 [3]. Since then, many short synthetic peptides playing roles in inflammation, extracellular matrix synthesis or pigmentation have been developed. These peptides are used for anti-oxidation, whitening effects, "Botox-like" wrinkle smoothing and collagen stimulation. 
Cosmeceutical peptides usually have certain features. Historically, it has always been assumed that the molecular weight of a peptide should be less than $500 \mathrm{Da}$, if not it could not pass skin barrier [4]. In addition, the peptide should have water solubility over $1 \mathrm{mg} / \mathrm{mL}$ and have no or few polar centers in its sequence [5]. Copper tripeptides, tetrapeptide PKEK, manganese tripeptide-1, soybean peptide, black rice oligopeptides and silk fibroin peptide have been on the market for several decades, but less in vivo efficacy data is available [5]. In general, their substance mixtures are examined in cosmetic formulations, so as to the actual effect of individual peptides on the skin still remains unclear in many cases.

Scientific research on peptides usually focus on identification of functional mechanism, and practical application for cosmetic and/or pharmaceutical use. In the last decade, the development of active peptides has established a new field in cosmeceutical and pharmaceutical skin care. To generate safety profile and functional data of peptide, in vivo animal test was usually chosen in the past. However, correctness of results from animal model for human skin has always been quested. This problem, using animals for testing purposes, finally leads to EU regulation (76/768/EEC, Feb. 2003), beginning in 2009, to prohibit use of animals to accumulating toxicological data for cosmetic ingredients.

As an alternative solution, artificial human skin models have been established and many of these are now commercially available. Several technologies have been introduced to design and develop artificial skin models which highly simulate complex structure of human skin [6,7]. The most common skin models were epidermis models using human skin epidermal cells, including EpiSkin ${ }^{\circledR}$ (L'Oreal, Levallois-Perret, France), EpiDerm ${ }^{\circledR}$ (MatTek Corporation, Ashland, MA, USA), SkinEthic ${ }^{\circledR}$ (SkinEthics, Lyon, France) and epiCS ${ }^{\circledR}$ (CellSystems, Troisdorf, Germany). Recently, some advanced skin models were commercialized, including Phenion ${ }^{\circledR}$ (Henkel, Düsseldorf, Germany) and NeoDerm ${ }^{\circledR}$ (Tegoscience, Seoul, Korea). These models have been proven to replace animal tests in pharmaceutical and cosmetic industries for evaluation of corrosion, skin irradiation and photo-toxicity [8]. Some of them can also be applied in basic research for clinical use [9].

Human skin gives protective, perceptive and communication functions to the body with resilient and relatively impermeable barrier. To develop agents to deliver pharmacy or active ingredients across skin tissues is a highly attractive topic in recent years. Using compounds or physical equipment to enhance cargo delivery causes some problems, for instance, skin toxicity, skin irritation, inconvenience and high costs $[10,11]$. Comparing with chemical or physical ways, peptide with cell or skin penetrating activity is an alternative choice. Cell-penetrating peptides (CPP) are peptides that can transport cargos such as chemical compounds, proteins, peptides, and nanoparticles into cells [12]. Most CPP sequences are rich in positively charged residues, and are internalized after interacting with negatively charged glycosaminoglycans (GAGs) and clustering on outer membrane surfaces [13]. For example, a modified PTD (Protein transduction domain) peptide from human immunodeficiency virus (HIV): tat (RKKRRQRRR) has been shown to have cell membrane penetration property and deliver therapeutic proteins into mammalian cells [14]. Another case is AID (arginine-rich intracellular delivery) peptides which successfully enter and deliver functional proteins into epidermis and dermis of mouse [15,16]. Many modified AID peptides (HGH6, TAT, R7) proven to penetrate into skin of living animals with cargos $[17,18]$. For example, R7-CsA could reach dermal lymphocytes and inhibit cutaneous inflammation [19]. These facts indicated a new approach for increasing delivery of poorly absorbed ingredients across skin tissue barriers.

Here a 10-residue peptide, covering major GAG binding motif of a human ribonuclease, is identified as a $\mathrm{CPP}_{\mathrm{AIF}}$ (anti-inflammatory $\mathrm{CPP}$ ). $\mathrm{CPP}_{\mathrm{AIF}}$ has been shown to possess epithelial cell, GAG and lipid binding properties as well as cell penetrating activity through macropinocytosis [20,21]. Notably, $\mathrm{CPP}_{\mathrm{AIF}}$ is able to deliver small fluorescent molecules, recombinant proteins, nanoparticles, and peptidomimetic drugs into cells [20]. Based on these facts, safety and potential of CPP AIF for cosmeceutical application were examined with skin cell and 3D-skin models following the Organization for Economic Co-operation and Development (OECD) guidelines with special focus on stability, safety, 
skin irritation, skin barrier function, chemico sensitization, bio-functions and transepidermal activity in this work.

\section{Materials and Methods}

\subsection{Stability Test of $C P P_{A I F}$ under Different Conditions}

All chemicals used in this study were purchased from Sigma-Aldrich (St. Louis, MO, USA). All cell lines were purchased from ATCC (American Type Culture Collection, Manassas, VA, USA). For dry powder stability test, $\mathrm{CPP}_{\mathrm{AIF}}$ (NYRWRCKNQN with unmodified $\mathrm{N}$ - and C-termini; AIF: anti-inflammation, synthesized by Kelowna International Scientific, Taipei, Taiwan) and was dissolved in water, concentration of $1 \mathrm{mg} / \mathrm{mL}$, and then freeze and dry into powder. Samples were separately incubated in 4 and $25^{\circ} \mathrm{C}$ for 1,3 and 7 days. These tubes were collected and stored at $-80^{\circ} \mathrm{C}$. For solution stability test, $\mathrm{CPP}_{\mathrm{AIF}}$ was dissolved in water to $1 \mathrm{mg} / \mathrm{mL}$ then used $0.2 \mu \mathrm{m}$ filter filted and dispense to $100 \mu \mathrm{L}$ in each tubes. Samples were separately incubated in specific temperatures, including $-20,4,30$ and $50{ }^{\circ} \mathrm{C}$ for $1,3,7,14,21,30$ and 60 days. These tubes were collected and stored at $-80^{\circ} \mathrm{C}$. Then, the remainder of $\mathrm{CPP}_{\mathrm{AIF}}$ were tested with high-performance liquid chromatography (HPLC) (Waters, Milford, MA, USA) Separation was performed on XBridge C18 column $(250 \mathrm{~mm} \times 4.6 \mathrm{~mm}$, particle size $5 \mu \mathrm{m}$, Waters). The HPLC condition and program: A buffer is $\mathrm{ddH}_{2} \mathrm{O}$ with $0.1 \%$ TFA (trifluoroacetic acid), B buffer is acetonitrile with $0.1 \%$ TFA. The flow rate is $1 \mathrm{~mL} / \mathrm{min}$ and acetonitrile gradient from 10 to $50 \%$ in $15 \mathrm{~min}$ and the percentage of acetonitrile raise to $100 \%$ from 16 to $20 \mathrm{~min}$.

\subsection{In Vitro Skin Irritation Test (OECD 439)}

The 3D reconstructed human epidermis tissue model: SkinEthic ${ }^{\mathrm{TM}}$ RHE (SkinEthics, Lyon, France) was used to evaluate whether $\mathrm{CPP}_{\mathrm{AIF}}$ cause skin irritation [8]. Testing procedure involved topical application of testing article ( $\left.\mathrm{CPP}_{\mathrm{AIF}}\right)$ to surface of epidermis and subsequent assessment of effect on cell viability. All 3D-skin tissues were incubated with growth medium for $2 \mathrm{~h}$ and then $\mathrm{CPP}_{\mathrm{AIF}}$ was add to final $1 \mathrm{mM}$ for $42 \mathrm{~min}$ treatment. After treatment, testing substance was washed out by 25 times with $1 \mathrm{~mL}$ phosphate buffered saline (PBS) and tissues were further incubated in growth medium for $42 \mathrm{~h}$. After incubation, growth medium was substituted by maintenance medium with 3-(4,5-dimethylthiazol-2-yl)-2,5-diphenyltetrazolium bromide (MTT) agent for $3 \mathrm{~h}$ incubation. Next, insert (with tissue) were washed with PBS and air dried. Formazan in tissues was extracted with isopropanol and measured by determining the OD at $570 \mathrm{~nm}$ using a microplate spectrophotometer (iMark Microplate Absorbance Reader, Bio-Rad, Hercules, CA, USA). Cell viability of treated models was normalized to the negative control, which was set to $100 \%$.

\subsection{In Vitro Skin Barrier Function Test (Developed from OECD TG 439)}

A test procedure was developed to test effect of $\mathrm{CPP}_{\mathrm{AIF}}$ on the barrier function on SkinEthic ${ }^{\mathrm{TM}}$ reconstructed human epidermis (RHE) based on the relevant procedure mentioned in OECD TG 439. This testing procedure involved topical application of $\mathrm{CPP}_{\mathrm{AIF}}$ onto surface of the epidermis model for $1 \mathrm{~h}$. After $1 \mathrm{~h}$ of exposure, $\mathrm{CPP}_{\mathrm{AIF}}$ was washed by $\mathrm{PBS}$ from the surface followed by application of detergent solution (1\% Triton X-100) onto surface of the tissue for another $2 \mathrm{~h}$. Then, washed the detergent solution and AlamarBlue cell viability assay (BUF012B, Bio-Rad, Hercules, CA, USA) was performed for assessment of cell viability. Cell viability of treated models was normalized to the negative control, which was set to $100 \%$.

\subsection{In Chemico Skin Sensitization: Direct Peptide Reactivity Assay (DPRA) (OECD 442C)}

The direct peptide reactivity assay (DPRA) is an in chemico method which quantified the remaining concentration of cysteine- or lysine-containing peptide after $24 \mathrm{~h}$ incubation with the test chemical at $25{ }^{\circ} \mathrm{C}$. Relative peptide concentration was measured by HPLC (Waters, Milford, MA, USA) with gradient elution and UV detection $(220 \mathrm{~nm})$. Cysteine and lysine peptide percent depletion values 
were calculated for a prediction model (Table 1). This model allowed to classify the test chemical to one of four reactivity classes used to support the discrimination between sensitisers and non-sensitisers. The study is carried out according to the OECD guideline 442C (2015).

Table 1. Cysteine 1:10/lysine 1:50 prediction model

\begin{tabular}{ccc}
\hline Mean of Cysteine and Lysine $\%$ Depletion & Reactivity Class & DPRA Prediction \\
\hline $0 \% \leq$ mean $\%$ depletion $\leq 6.38 \%$ & No or minimal reactivity & Negative \\
$6.38 \% \leq$ mean $\%$ depletion $\leq 22.62 \%$ & Low reactivity & \\
$22.62 \% \leq$ mean $\%$ depletion $\leq 42.47 \%$ & Moderate reactivity & Positive \\
$42.47 \% \leq$ mean $\%$ depletion $\leq 100 \%$ & High reactivity & \\
\hline
\end{tabular}

\subsection{Macrophage Inflammation Assay}

Macrophage inflammatory assay were carried out to evaluate whether $\mathrm{CPP}_{\mathrm{AIF}}$ displayed anti-inflammation potential [22-24]. In this experiment, macrophage (Raw264.7) cells were seeded in 96-well plates $\left(5 \times 10^{5}\right.$ cells $\left./ \mathrm{mL}\right)$ and allowed to attach overnight. After attachment, cells were incubated with various concentrations of $\mathrm{CPP}_{\mathrm{AIF}}$ for $1 \mathrm{~h}$ and followed by stimulation with $1 \mu \mathrm{g} / \mathrm{mL}$ of LPS (lipopolysaccharide). No LPS-added cells were considered as control groups. After incubation, the amount of TNF- $\alpha$ and IL-6 in the medium were analyzed by enzyme linked immunosorbent assay (\# KHC3011 and \#EH2IL6, Thermo Fisher, Waltham, MA, USA). Cell viability was measured by AlamarBlue cell viability assay (BUF012B, Bio-Rad, Hercules, CA, USA).

\subsection{Mast Cell Degranulation Assay}

Inhibitory effects on release of $\beta$-hexosaminidase in RBL-2H3 (rat-basophilic leukemia cell line) were evaluated by a cell degranulation assay [25]. Briefly, $0.2 \mathrm{~mL}$ of $5 \times 10^{5}$ cells/mL RBL-2H3 cells were seed in 24-well plates (in Minimum Essential Medium (MEM) containing 10\% Fetal Bovine Serum (FBS), streptomycin $(100 \mu \mathrm{g} / \mathrm{mL})$ and penicillin (100 units/mL)) and sensitized with anti-DNP IgE $(0.45 \mu \mathrm{g} / \mathrm{mL})$. These cells were washed with Siraganian buffer $(5 \mathrm{mM} \mathrm{KCl}, 0.4 \mathrm{mM} \mathrm{MgCl}, 119 \mathrm{mM}$ $\mathrm{NaCl}, 25 \mathrm{mM}$ piperazine-N,N 2-bis(2-ethane sulfonic acid (PIPES), and $40 \mathrm{mM} \mathrm{NaOH}, \mathrm{pH}$ 7.2) with glucose, $1 \mathrm{mM} \mathrm{CaCl}_{2}$, and $0.1 \%$ bovine serum albumin (BSA). After washing, these cell were incubated in $160 \mu \mathrm{L}$ of the PBS for $10 \mathrm{~min}$ at $37^{\circ} \mathrm{C}$ and then $20 \mu \mathrm{L}$ of test sample solution or calcimycin (final $1 \mathrm{mM}$ ) was added and further incubated for $10 \mathrm{~min}$. The plate was cooling on ice for $10 \mathrm{~min}$ to stop reaction. $50 \mu \mathrm{L}$ of supernatant was transferred to 96-well plate and added with $50 \mu \mathrm{L}$ of substrate (1 mM p-nitrophenyl $N$-acetyl- $\beta$-D-glucosaminide) in $0.1 \mathrm{M}$ citrate buffer $(\mathrm{pH} 4.5)$ at $37^{\circ} \mathrm{C}$ for $2.5 \mathrm{~h}$. The reaction was stopped by adding $200 \mu \mathrm{L}$ of carbonate-bicarbonate buffer $(0.1 \mathrm{M}, \mathrm{pH} 10.0)$. The value of $\mathrm{A}_{405}$ was measured with a microplate reader.

\subsection{Internalization of $C P P_{A I F}$ in Human Keratinocyte (HaCaT)}

Confocal Laser-scanning Microscopy (CLSM, Zeiss Cell Observer-Z1, Baden-Württemberg, Germany) was performed to assess distribution of TMR-labeled CPP $\mathrm{AIF}$ (tetramethylrhodamineNYRWRCKNQN, synthesized by Kelowna International Scientific, Taipei, Taiwan) in human keratinocytes, HaCaT. First, apply a layer of type I collagen on a glass cover slip, dry and sterilize the cover slip with UV light. Then, culture the HaCaT cells $(1 \times 103$ per slip $)$ on the coverslip for $16 \mathrm{~h}$. The attached HaCaT cells were cultured with $20 \mu \mathrm{M}$ of the TMR- CPP AIF for $30 \mathrm{~min}$, observed with CLSM (63× oil-immersion objective lens), and photographed under same exposure conditions.

\subsection{Transepidermal Measurement of CPP AIF by Reconstructed Human Epidermis Tissue Model}

3D human epidermis tissue model (SkinEthic ${ }^{\mathrm{TM}}$ RHE, SkinEthics, Lyon, France) and two kinds of $\mathrm{CPP}_{\mathrm{AIF}}$-containing emulsion systems (water-in-oil emulsion $(\mathrm{W} / \mathrm{O})$ and oil-in-water emulsion $(\mathrm{O} / \mathrm{W})$ ) were prepared for the transepidermal measurements. Formulation contents of the W/O and O/W 
are listed in Tables S1 and S2. All 3D-skin tissues were incubated with growth medium for $2 \mathrm{~h}$ and then $0.1 \mathrm{~mL}$ formulated $\mathrm{CPP}_{\mathrm{AIF}}(0.1 \mathrm{mM})$ emulsions were add to top of the tissues for $1 \mathrm{~h}$ treatment. After treatment liquid beneath the model was collected for HPLC quantification. Transepidermal rate was calculated by measuring the amount of $\mathrm{CPP}_{\mathrm{AIF}}$ in medium beneath the 3D model by HPLC ((concentration of the beneath liquid/concentration of the topical exposure) $\times 100)$.

\subsection{Statistical Analyses}

All statistical analyses were processed by GraphPad Prism version 5.01 for Windows 548 (GraphPad Software, La Jolla, CA, USA). Each value was the average of three measurements, where the presented data was the mean \pm SD and all means were compared by one-way ANOVA.

\section{Results}

\subsection{Stability of $C P P_{\text {AIF }}$ under Different Conditions}

$\mathrm{CPP}_{\text {AIF }}$ was incubated at a specified temperature $\left(4{ }^{\circ} \mathrm{C}\right.$ and $\left.25{ }^{\circ} \mathrm{C}\right)$ and analyzed remaining quantity by HPLC. The molecular weight of $\mathrm{CPP}_{\text {AIF }}$ was validated by matrix-assisted laser desorption/ ionization-time-of-flight (MALDI-TOF) mass spectrometry. The result indicated that $\mathrm{m} / \mathrm{z}$ of $\mathrm{CPP}$ AIF was 1381.1 as expected (Figure S1). The results in Figure 1 show that $\mathrm{CPP}_{\text {AIF }}$ maintained intact close to $100 \%$ in dry powder form at low temperature $\left(4^{\circ} \mathrm{C}\right)$ and normal temperature $\left(25^{\circ} \mathrm{C}\right)$ up to 1 week, indicating that preservation of $\mathrm{CPP}_{\mathrm{AIF}}$ in dry powder form could effectively prevent peptide precipitation and fragmentation.

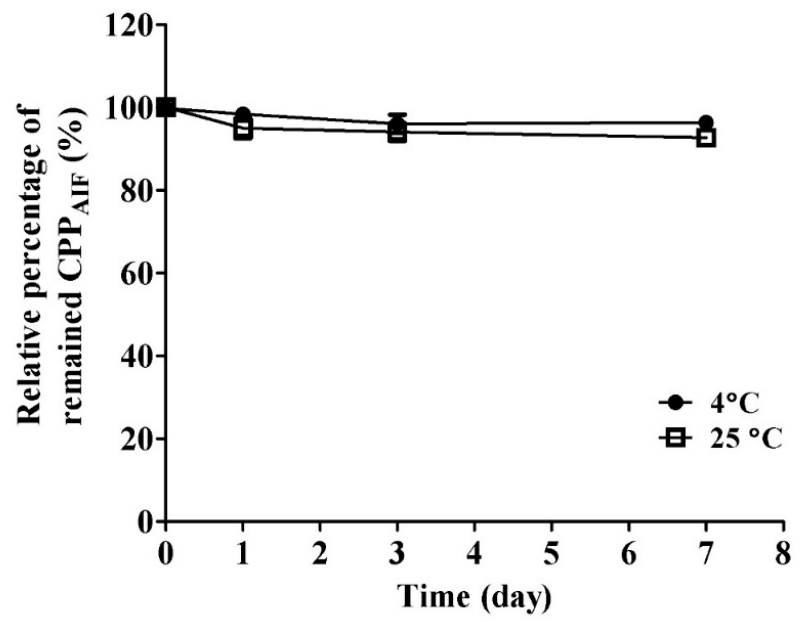

Figure 1. Stability of $\mathrm{CPP}_{\mathrm{AIF}}$ stored as dry powder at different temperatures. Each sample was dissolved in milliQ $\mathrm{H}_{2} \mathrm{O}$, and filtered through $0.2 \mu \mathrm{m}$ filter, then freeze dried into powder form. The samples $(100 \mu \mathrm{L}, 1 \mathrm{mg} / \mathrm{mL})$ were separately incubated at $4{ }^{\circ} \mathrm{C}$ and $25{ }^{\circ} \mathrm{C}$ for 1,3 , and 7 days. The residual amount of $\mathrm{CPP}_{\mathrm{AIF}}$ ingredient was quantified by HPLC equipped with $\mathrm{C} 18$ column.

$\mathrm{CPP}_{\mathrm{AIF}}$ under different solutions or temperatures was further examined to explore suitable storage condition. It was dissolved in $\mathrm{ddH}_{2} \mathrm{O}$ at different temperatures and time to examine which solution was suitable for storage. First, $\mathrm{CPP}_{\text {AIF }}$ was dissolved in water at a concentration of $1 \mathrm{mg} / \mathrm{mL}$ passed through $0.2 \mu \mathrm{m}$ filter, and incubated at different temperatures. After one week, residual quantity of $\mathrm{CPP}_{\mathrm{AIF}}$ was still more than $90 \%$ when tested at $-20{ }^{\circ} \mathrm{C}$ and $4{ }^{\circ} \mathrm{C}$, but that of $\mathrm{CPP}_{\mathrm{AIF}}$ incubated at $30^{\circ} \mathrm{C}$ and $50^{\circ} \mathrm{C}$ dropped to about $70 \%$ (Figure 2). Moreover, after storage for 30 days intact $\mathrm{CPP}_{\mathrm{AIF}}$ retained in solution was measured to be $81 \%$ at $-20{ }^{\circ} \mathrm{C}, 73 \%$ at $4{ }^{\circ} \mathrm{C}, 36 \%$ at $30{ }^{\circ} \mathrm{C}$, and $17 \%$ at $50{ }^{\circ} \mathrm{C}$, indicating that $\mathrm{CPP}_{\mathrm{AIF}}$ had better stability at low temperature environment $\left(-20^{\circ} \mathrm{C}\right.$ and $\left.4{ }^{\circ} \mathrm{C}\right)($ Figure 2$)$. MALDI-TOF mass spectrometry was applied to validate the molecular weight of residual $\mathrm{CPP}_{\mathrm{AIF}}$ as shown in the signal of HPLC chromatogram (Figure S2). 


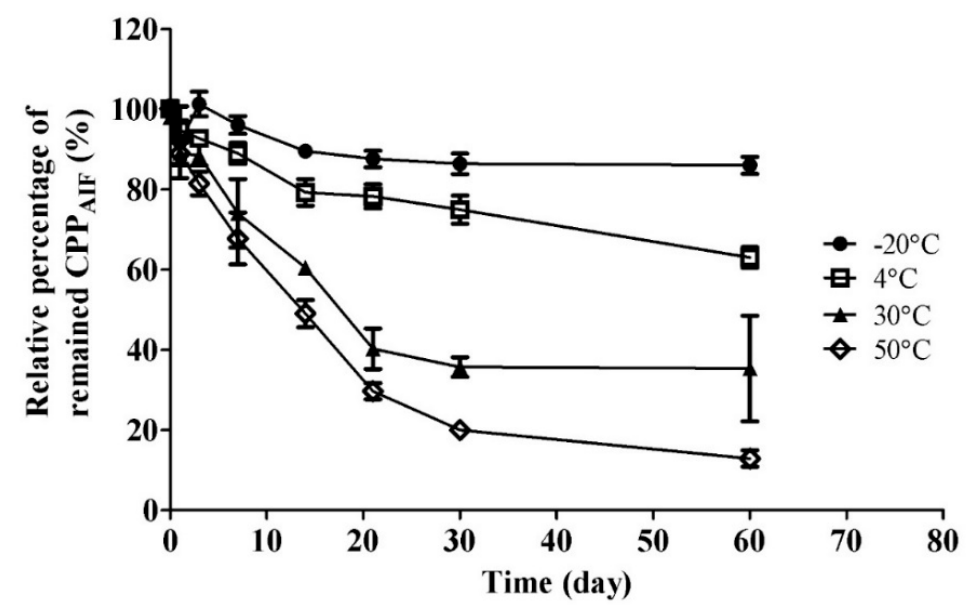

Figure 2. Stability of $\mathrm{CPP}_{\mathrm{AIF}}$ stored in water at different temperature. Stability of $\mathrm{CPP}_{\mathrm{AIF}}$ in water at various temperature $\left(-20^{\circ} \mathrm{C}, 4^{\circ} \mathrm{C}, 30^{\circ} \mathrm{C}, 50{ }^{\circ} \mathrm{C}\right)$ for different time duration. Each sample $(100 \mu \mathrm{L}$, $1 \mathrm{mg} / \mathrm{mL}$ ) was filtered through $0.2 \mu \mathrm{m}$ filter, and residual amount of $\mathrm{CPP}_{\text {AIF }}$ ingredient was quantified by HPLC equipped with C18 column.

\subsection{Safety of $C P P_{A I F}$}

In vitro skin irritation testz of $\mathrm{CPP}_{\mathrm{AIF}}$ were carried out following OECD Test Guideline No. 439 (2015), using a reconstructed human epidermis test method.

As shown in Figure 3, relative viability of negative control (NC, PBS), positive control (PC, 5\% sodium dodecyl sulphate, $\mathrm{SDS})$, and $\mathrm{CPP}_{\mathrm{AIF}}(1 \mathrm{mM})$ was determined to be respectively: $100.0 \pm 4.8 \%$, $1.44 \pm 0.8 \%$, and $90.3 \pm 3.2 \%$, clearly suggesting that $\mathrm{CPP}_{\mathrm{AIF}}(1 \mathrm{mM})$ did not cause skin irritation (no category) according to the classification of OECD 439.

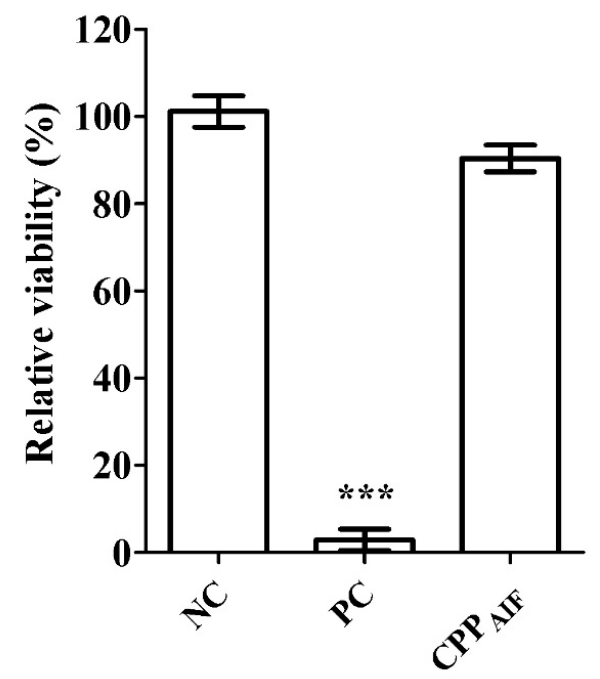

Figure 3. In vitro skin irritation test of $\mathrm{CPP}_{\mathrm{AIF}}$ in SkinEthic ${ }^{\mathrm{TM}} \mathrm{RHE}$ model. 3D reconstructed human epidermis tissues were incubated with growth medium for $2 \mathrm{~h}$ followed by treatment with NC, PC, and $1 \mathrm{mM} \mathrm{CPP}_{\mathrm{AIF}}$ for $42 \mathrm{~min}$. Then the tissues were washed and further incubated in growth medium for $42 \mathrm{~h}$. Afterwards, the growth medium was substituted with maintenance medium containing MTT agent for an additional $3 \mathrm{~h}$ incubation. Next, the insert (with tissue) was washed with PBS and air dried. Formazan in tissues was extracted with isopropanol and measured by OD at $570 \mathrm{~nm}$. PBS was applied as negative control (NC) and set as 100\% (mock), 5\% SDS was applied as positive control (PC). *** $p<0.001$ versus the NC. 
$\mathrm{CPP}_{\mathrm{AIF}}$ was subsequently applied to in vitro skin barrier function test (developed from OECD TG 439). A normal stratum corneum was multilayered containing essential lipid profile to produce desired functional barrier with robustness to resist rapid penetration of cytotoxic chemicals, e.g., SDS or Triton X-100. Here, a 3D human epidermis tissue model, SkinEthic ${ }^{\mathrm{TM}} \mathrm{RHE}$, was used for skin barrier function tests. Tissues incubated with $\mathrm{CPP}_{\mathrm{AIF}}(1 \mathrm{mM})$ remained cell viability over $80 \%$, which was considered not influencing barrier function of the tissue. As shown in Figure 4, relative viability of negative control $\left(\mathrm{NC}, \mathrm{H}_{2} \mathrm{O}\right)$, positive control (PC, $\left.5 \% \mathrm{SDS}\right)$, and $\mathrm{CPP}_{\mathrm{AIF}}(1 \mathrm{mM})$ was respectively $100.0 \pm 6.2 \%, 24.0 \pm 3.3 \%$, and $95.6 \pm 2.8 \%$, evidently indicating that $\mathrm{CPP}_{\mathrm{AIF}}$ would not impair the skin barrier function of the 3D epidermis tissue model.

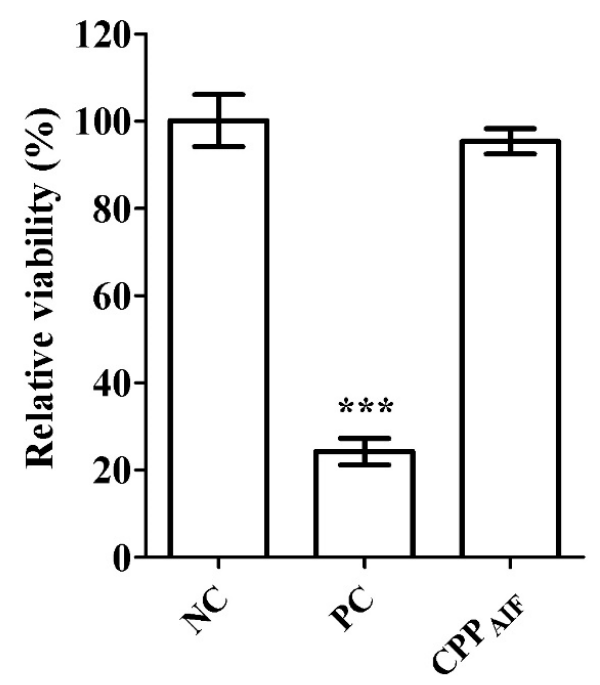

Figure 4. In vitro skin barrier function test of $\mathrm{CPP}_{\mathrm{AIF}}$ in SkinEthic ${ }^{\mathrm{TM}} \mathrm{RHE}$ model. 3Dreconstructed human epidermis tissues were exposed with NC, PC, and $1 \mathrm{mM} \mathrm{CPP}_{\text {AIF }}$ for $1 \mathrm{~h}$. The CPP $\mathrm{AIF}$ was washed with PBS from the surface followed by application of detergent solution (1\% Triton X-100) onto surface of the tissues for another $2 \mathrm{~h}$. The tissues were washed with PBS and cell viability was measured by AlamarBlue cell viability assay. PBS was applied as negative control (NC) set as $100 \%$ (mock) and 5\% SDS was applied as positive control (PC). ${ }^{* *} p<0.001$ versus the NC.

Finally, in chemico skin sensitization of $\mathrm{CPP}_{\mathrm{AIF}}$ was tested following OECD Test Guideline No. 442C. The mean of cysteine and lysine \% depletion of $100 \mathrm{mM}$ cinnamaldehyde (positive control), phenoxyethanol, caprylyl glycol, hexalene glycol, 1,3-butanediol and $0.1 \mathrm{mM} \mathrm{CPP}_{\text {AIF }}$ was respectively calculated to be $65.07,0.56,2.53,0.63,-0.12$ and 0.74 (Table 2).

Table 2. DPRA calculation according to prediction model.

\begin{tabular}{cccccc}
\hline Test Item & $\begin{array}{c}\text { Concentration } \\
(\mathbf{m M})\end{array}$ & $\begin{array}{c}\text { Lysine } \\
\text { Depletion }\end{array}$ & $\begin{array}{c}\text { Cysteine } \\
\text { Depletion }\end{array}$ & $\begin{array}{c}\text { Mean of Cysteine and } \\
\text { Lysine \% Depletion }\end{array}$ & $\begin{array}{c}\text { DPRA*1 } \\
\text { Prediction }\end{array}$ \\
\hline Cinnamaldehyde & 100 & 53.82 & 76.33 & 65.07 & Sensitiser \\
Phenoxyethanol & 100 & -0.25 & 1.38 & 0.56 & Non-sensitiser \\
Caprylyl glycol & 100 & 2.34 & 2.72 & 2.53 & Non-sensitiser \\
Hexalene glycol & 100 & -0.36 & 1.62 & 0.63 & Non-sensitiser \\
1,3-Butanediol & 100 & -0.36 & 0.13 & -0.12 & Non-sensitiser \\
CPP $_{\text {AIF }}$ & 0.1 & 1.02 & 0.45 & 0.74 & Non-sensitiser \\
\hline
\end{tabular}

*1: Direct Peptide Reactivity Assay (OECD Test Guideline No. 442C).

The HPLC chromatograms for cysteine and lysine depletion quantification of $\mathrm{CPP}_{\text {AIF }}$ were shown in Figure S3. The value of $\mathrm{CPP}_{\mathrm{AIF}}$ was lower than $19 \%$ and thus classified as "Non-sensitizer" according to OECD $442 \mathrm{C}$ like other regulatory approved cosmetic ingredients. 


\subsection{Bio-Function of $C P P_{A I F}$ : Anti-Inflammation without Sensitization}

Inflammation inhibition effect of $\mathrm{CPP}_{\mathrm{AIF}}$ on macrophage cells was tested at various concentrations of 1 and $0.1 \mu \mathrm{M}$. As shown in Figure 5A, $0.1 \mu \mathrm{M} \mathrm{CPP}_{\mathrm{AIF}}$ inhibited $22.1 \pm 1.2 \%$ TNF- $\alpha$ secretion and $1 \mu \mathrm{M} \mathrm{CPP}_{\mathrm{AIF}}$ showed stronger inhibition effect of $56.7 \pm 2.5 \% .0 .1 \mu \mathrm{M}$ and $1 \mu \mathrm{M} \mathrm{CPP}$ AIF also inhibited $18.3 \pm 3.4 \%$ and $40 \pm 4.2 \%$ of IL-6 secretion, respectively (Figure 5B). These results implied a dose-dependent relationship between the concentration of $\mathrm{CPP}_{\mathrm{AIF}}$ (from $0 \sim 1 \mu \mathrm{M}$ ) and the amount of TNF- $\alpha$ or IL- 6 inhibition. Nevertheless, cell viability remained $85.2 \pm 4.25 \%$ at $\mathrm{CPP}_{\mathrm{AIF}}$ concentration of $1 \mu \mathrm{M}$. Taken together, $\mathrm{CPP}_{\mathrm{AIF}}$ might be a potential ingredient with skin protectant function, especially anti-photo aging [26,27] related to the anti-inflammatory effects [28].

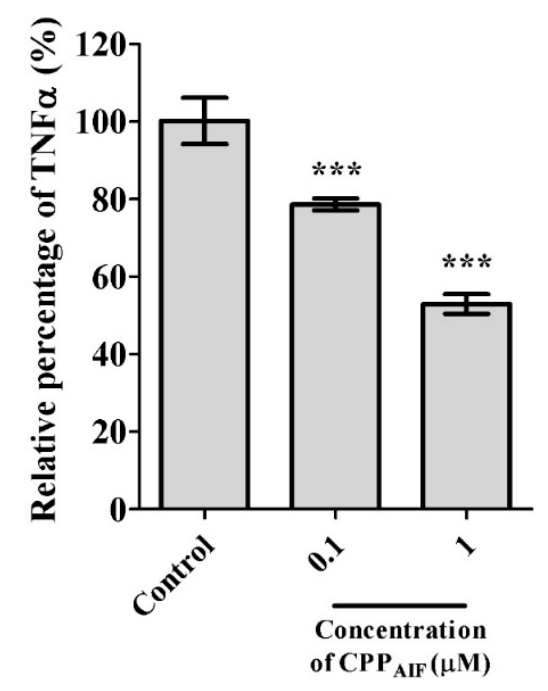

(A)

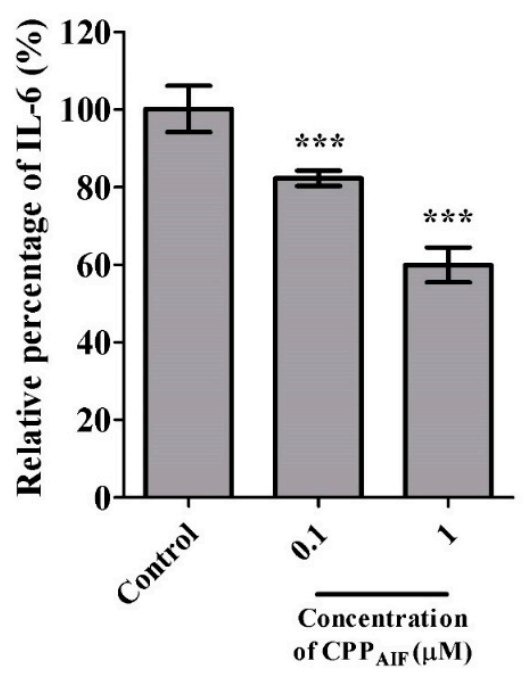

(B)

Figure 5. Anti-inflammation activity of $\mathrm{CPP}_{\mathrm{AIF}}$. Raw264.7 macrophage cells were seeded in 96-well plates $\left(5 \times 10^{5}\right.$ cells $\left./ \mathrm{mL}\right)$ and allowed to attach overnight. After attachment, the cells were incubated with various concentrations of $\mathrm{CPP}_{\mathrm{AIF}}$ for $1 \mathrm{~h}$ followed by stimulation with $1 \mu \mathrm{g} / \mathrm{mL}$ of LPS. The control group was not treated with LPS and its cytokine secretion was set as $100 \%$ (mock). The amounts of TNF $\alpha$ (A) and IL-6 (B) in the medium were analyzed by ELISA. Cell viability was measured by AlamarBlue cell viability assay. ${ }^{* * *} p<0.001$ versus the control group. 
The sensitization of $\mathrm{CPP}_{\text {AIF }}$ was evaluated by mast cell degranulation assay. Here RBL-2H3 cells were treated with various concentrations $(0,0.1,1,2,5,10 \mu \mathrm{M})$ of $\mathrm{CPP}_{\mathrm{AIF}}$. Granule release represented by $\beta$-hexoaminidase was induced by A23187 (Calcimycin) as positive control (PC). In this experiment $\mathrm{CPP}_{\mathrm{AIF}}$ under $10 \mu \mathrm{M}$ did not induce any mast cell degranulation release (Figure 6) while cell viability remained over $90 \%$. This result indicated that $\mathrm{CPP}_{\mathrm{AIF}}$ would not induce any allergic effect in epidermal tissue [29].

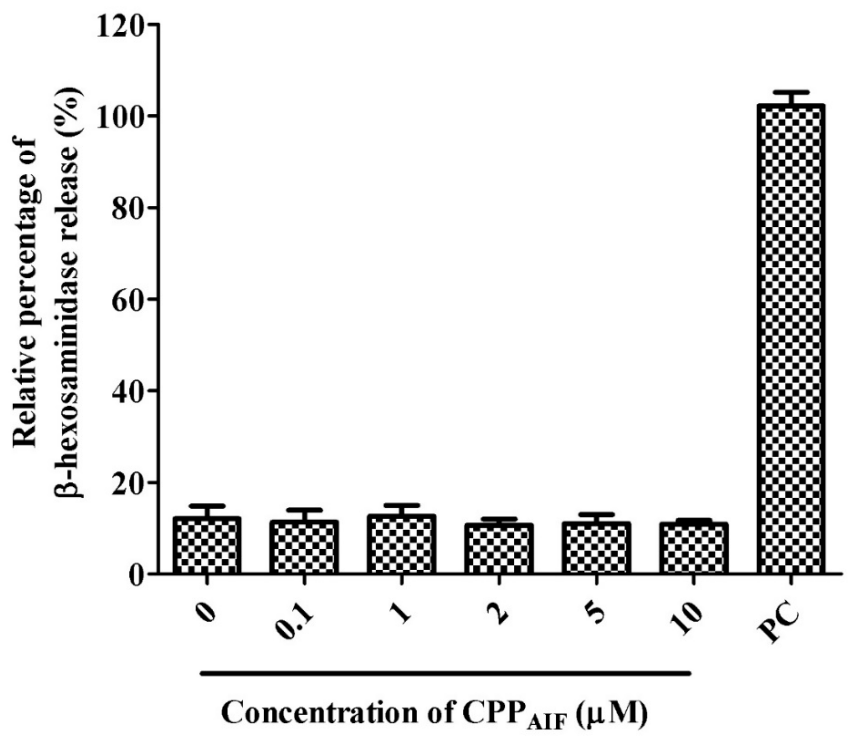

Figure 6. Sensitization test of $\mathrm{CPP}_{\mathrm{AIF}}$. The sensitization of $\mathrm{CPP}_{\mathrm{AIF}}$ was evaluated by mast cell degranulation assay. RBL-2H3 mast cells $\left(5 \times 10^{5}\right)$ were treated with various concentrations $(0,0.1,1,2$, $5,10 \mu \mathrm{M}$ ) of $\mathrm{CPP}_{\mathrm{AIF}}$. The positive control (PC) was treated with $1 \mathrm{mM} \mathrm{A} 23187$ (calcimycin) and the amount of its granule release was set as $100 \%$ (mock).

\subsection{Cell Penetration and Transepidermal Test. of $C P P_{A I F}$ :}

First, epidermal cell penetration activity of $\mathrm{CPP}_{\mathrm{AIF}}$ was measured in human keratinocyte $\mathrm{HaCaT}$ cells. The cells were incubated with $20 \mu \mathrm{M}$ TMR-CPP $\mathrm{AIF}$ at $37^{\circ} \mathrm{C}$ for $30 \mathrm{~min}$ prior to observation by CLSM (Scale bar: $10 \mu \mathrm{m}$ ). Nuclei were stained with DAPI (4',6-diamidino-2-phenylindole). As shown

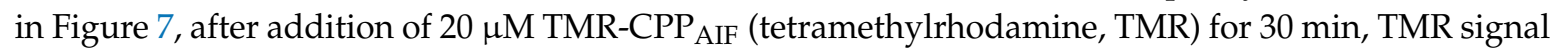
was clearly detected in the cells (Figure 7). A strong signal accumulation in the cytoplasm showed that TMR-CPP AIF internalized into the cells. Such effect was observed while the skin barrier function still maintained well as investigated by 3D human epidermis tissue model. This result indicated that TMR-CPP $_{\text {AIF }}$ could penetrate skin tissue without interupting function of skin tissue.

After confirming the cell penetration activity of $\mathrm{CPP}_{\mathrm{AIF}}$ to normal human keratinocyte, transepidermal activity of $\mathrm{CPP}_{\mathrm{AIF}}$ in different formulations was evaluated by $3 \mathrm{D}$ reconstructed human epidermis tissue model. After $4 \mathrm{~h}$ of exposure the liquid at the bottom of the 3D model was collected and analyzed by HPLC. As shown in Figure S4, CPP AIF appeared as a sharp peak at retention time of $9 \mathrm{~min}$. It was also observed that both emulsion compositions did not influence stability of $\mathrm{CPP}_{\mathrm{AIF}}$, indicating that $\mathrm{CPP}_{\mathrm{AIF}}$ could be added to properly designed formulation as a functional cosmetic ingredient. 

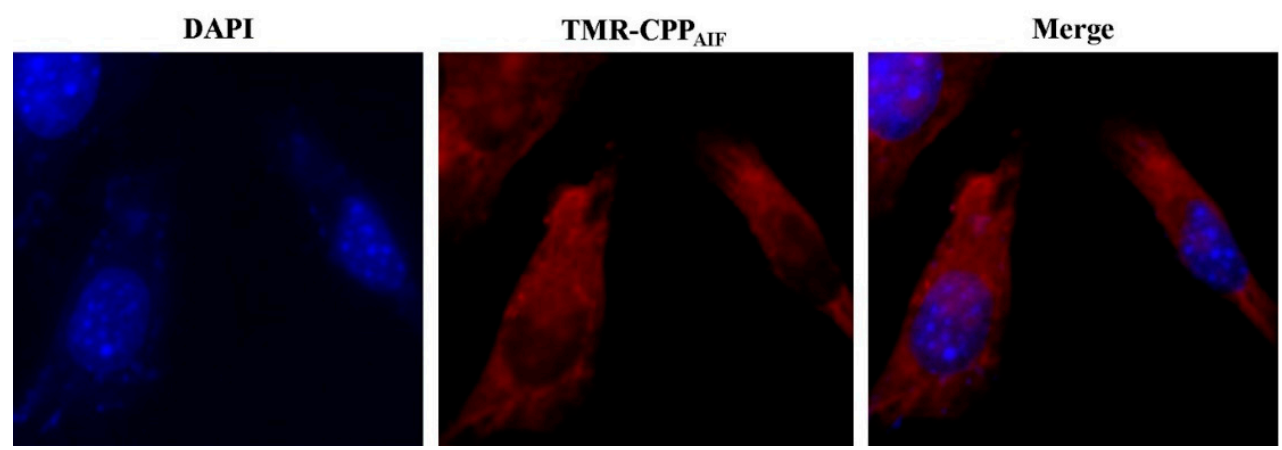

Figure 7. Internalization of TMR-CPP $\mathrm{AIF}$. HaCaT cells $\left(1 \times 10^{3}\right)$ were seeded on collagen I coated cover slide and incubated at $37^{\circ} \mathrm{C}$ for $16 \mathrm{~h}$. The cells were then incubatd with $20 \mu \mathrm{M}$ of TMR-CPP AIF at $37^{\circ} \mathrm{C}$ for $30 \mathrm{~min}$. After washing and fixing, the cells were mounted and monitored by confocal microscopy. Red: TMR; Blue: nuclear staining with DAPI. (Magnification: 63×).

Transepidermal degree of $\mathrm{CPP}_{\mathrm{AIF}}$ was further calculated according to HPLC results. ((concentration of $\mathrm{CPP}_{\mathrm{AIF}}$ in the beneath liquid/concentration of $\mathrm{CPP}_{\mathrm{AIF}}$ in the topical exposure) * 100). As shown in Figure 8, after $4 \mathrm{~h}$ of exposure to the emulsions (100 $\mu \mathrm{L}$ containing $100 \mu \mathrm{M} \mathrm{CPP}$ AIF $)$, $\mathrm{CPP}_{\mathrm{AIF}}$ present at the bottom of the 3D skin tissues $\mathrm{W} / \mathrm{O}$ and $\mathrm{O} / \mathrm{W}$ formulations was determined to be respectively $41.4 \pm 3.6 \%$ and $28.4 \pm 1.7 \%$ respectively in $\mathrm{W} / \mathrm{O}$ and $\mathrm{O} / \mathrm{W}$ formulations. The transepidermal activity of $\mathrm{W} / \mathrm{O} \mathrm{CPP}_{\mathrm{AIF}}$ was evidently higher than that of $\mathrm{O} / \mathrm{W}$ formulation. Taken together, appropriate formulation such as $\mathrm{W} / \mathrm{O}$ emulsion in this study could evidently facilitate transepidermal penetration of $\mathrm{CPP}_{\mathrm{AIF}}$.

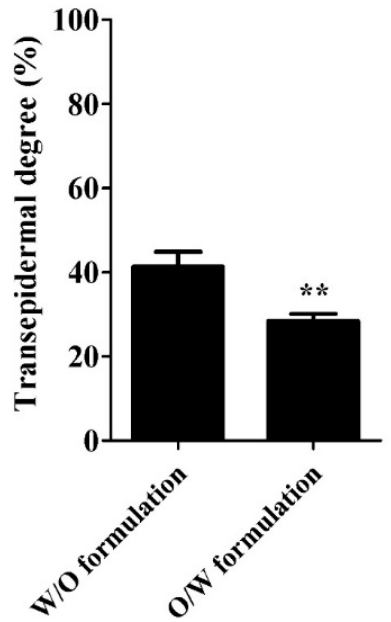

Figure 8. Transepidermal degree of formulated $\mathrm{CPP}_{\mathrm{AIF}}$ in SkinEthic ${ }^{\mathrm{TM}} \mathrm{RHE}$ model. All 3D reconstructed human epidermis tissues were incubated with growth medium for $2 \mathrm{~h}$, then $0.1 \mathrm{~mL}$ formulated $\mathrm{CPP}_{\mathrm{AIF}}$ $(0.1 \mathrm{mM})$ emulsions were added to the top of the tissues and incubated for $1 \mathrm{~h}$. After treatment the liquid beneath the 3D skin model was collected for HPLC quantification. Transepidermal degree was calculated by measuring the amount of $\mathrm{CPP}_{\mathrm{AIF}}$ in the liquid beneath the 3D skin model using HPLC. ** $p<0.01$ versus the $\mathrm{W} / \mathrm{O}$ formulation group.

We further examined skin barrier function of the 3D model after $4 \mathrm{~h}$ of exposure to formulated $\mathrm{CPP}_{\mathrm{AIF}}$. As shown in Figure 9, appropriate W/O formulations promoted $\mathrm{CPP}_{\mathrm{AIF}}$ penetration into stratum corneum while at the same time maintained the robustness barrier function of the epidermis. The 3D models incubated with $\mathrm{W} / \mathrm{O} \mathrm{CPP}_{\mathrm{AIF}}$ showed a higher relative cell viability of $76.5 \pm 8.5 \%$ than $\mathrm{O} / \mathrm{W} \mathrm{CPP}$ AIF formulation $(43.3 \pm 7.8 \%)$. Relative cell viability of negative control $\left(\mathrm{NC}, \mathrm{H}_{2} \mathrm{O}\right)$ equaled to $100.0 \pm 9.6 \%$. Thus, $\mathrm{W} / \mathrm{O} \mathrm{CPP}$ AIF displayed a better transepidermal degree with slight disruption effect on disruption of skin barrier function. 


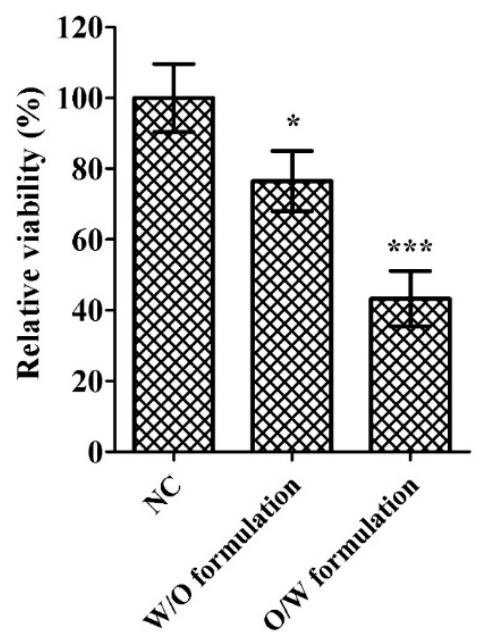

Figure 9. In vitro skin barrier function test of formulated $\mathrm{CPP}_{\mathrm{AIF}}$ in SkinEthic ${ }^{\mathrm{TM}}$ RHE model. $3 \mathrm{D}$ reconstructed human epidermis tissues were exposed with formulated $\mathrm{CPP}_{\mathrm{AIF}}(0.1 \mathrm{mM} \mathrm{CPP}$ AIF $)$ for $1 \mathrm{~h}$. Then $\mathrm{CPP}_{\text {AIF }}$ was washed by PBS from the surface followed by application of detergent solution ( $1 \%$ Triton $\mathrm{X}-100)$ onto surface of the tissues for another $2 \mathrm{~h}$. The tissues were washed and cell viability was measured by AlamarBlue cell viability assay. $\mathrm{H}_{2} \mathrm{O}$ was applied as negative control (NC) in which cell viability was set as $100 \%$ (mock). ${ }^{*} p<0.05$ and ${ }^{* * *} p<0.001$ versus the NC.

\section{Discussion}

Since 2000 the application of peptides in cosmeceutical products has rapidly increased, and this trend has sped up research and knowledge of physiological properties of peptides. Now, researchers have identified peptide sequences for penetration into skin layers or different cosmetic activities (e.g., anti-ageing, antioxidant, whitening) [2]. The commercial potential for these bio-functional peptides is high, especially for peptides with excellent stability and no toxicity. Many peptides were reported to have different cosmetic activities, but some clinical study results about these peptides were obtained using formulations containing peptides and other active ingredients. These trials did not clearly differentiate the role of peptide from other actives in the formulation. Hence, the results could not be claimed clearly to be the effect of the peptides for skin benefits [2].

Here $\mathrm{CPP}_{\mathrm{AIF}}$ was tested with regulatory affair approved methods and clear formulations, therefore the safety datum and anti-inflammatory activity were highly credible. $\mathrm{CPP}_{\mathrm{AIF}}$ in $\mathrm{W} / \mathrm{O}$ or $\mathrm{O} / \mathrm{W}$ formulation could pass through 3D human tissue model. Our $\mathrm{CPP}_{\mathrm{AIF}}$ showed skin penetration activity without disrupting skin barrier function, and its anti-inflammatory activity might alleviate slight inflammation caused by conventional transepidermal methods [2]. As a CPP, this peptide could also carrier cargos into epidermal cell in skin tissue. Skin tissue is composed by four different layers: stratum corneum, viable epidermis, dermis and subcutaneous connective tissue [30]. This structure efficiently blocks penetration of extraneous molecules in to deeper tissue. It has been reported that TAT can be apply for topical drug-delivery, but high cell penetrating activity might increase some risks which is that TAT might bring drug penetrating cell-layers into deeper tissues [30]. Unlike TAT, our CPPAIF only penetrate into cytosol of epidermal cells without exocytosis property [21], hence it would not be a concern of drug effect. Environmental conditions of skin surface might be tough for bio-molecules (peptide). Cream formulation could provide a stable environment for cosmetic ingredients and remained longer on the skin surface. Some cosmeceutical peptides were also applied in cream formulation [2]. To reduce these challenges that might disrupt stability of CPPAIF, our strategy was applied peptide with $\mathrm{W} / \mathrm{O}$ or $\mathrm{O} / \mathrm{W}$ formulation as a mimic of cream in transepidermal test. This standard cosmetic formulation might prove a relatively stable condition for CPPAIF and slightly enhance transepidermal activity. Taken together, CPPAIF itself has been demonstrated to be safe and effective for cosmeceutical use. Comparison between $\mathrm{W} / \mathrm{O}$ and $\mathrm{O} / \mathrm{W}$ formulations revealed that the former was more suitable for further application, and the latter with reduced skin barrier function 
presumably due to formulation components, which might be improved with alternative composition or process. With these facts, $\mathrm{CPP}_{\mathrm{AIF}}$ was convinced to be a perfect choice for carrying active ingredients through skin tissue and that will be our next goal.

\section{Conclusions}

$\mathrm{CPP}_{\mathrm{AIF}}$, a GAG binding peptide, could penetrate cell membranes with cargos in living animals and was proven to be stable in powder form under room temperature or in water solution under $-20{ }^{\circ} \mathrm{C}$ using HPLC analysis. Following OECD guidelines, $\mathrm{CPP}_{\mathrm{AIF}}$ was evaluated and characterized without skin irritation, skin sensitization and did not disrupt skin barrier function using 3D skin model. In addition to high safety $\mathrm{CPP}_{\mathrm{AIF}}$ was identified to inhibit inflammation by decreasing inflammatory cytokines, TNF- $\alpha$ and IL-6, using macrophage model. With this bio-function, $\mathrm{CPP}_{\mathrm{AIF}}$ was further proven to not have sensitization effects. The result of penetration test in $\mathrm{HaCaT}$ cells verified $\mathrm{CPP}_{\mathrm{AIF}}$ for cargo (TMR in this case) delivery into cell in less $30 \mathrm{~min}$. Finally, two commonly used formulations were applied to evaluate transepidermal activity of $\mathrm{CPP}_{\mathrm{AIF}}$ in 3D skin model in order to imitate real cosmetic applications, and $\mathrm{W} / \mathrm{O}$ formulation of $\mathrm{CPP}_{\mathrm{AIF}}$ was identified as a better choice to efficiently penetrate 3D skin with slight disruption of skin barrier function.

Supplementary Materials: The following are available online at http://www.mdpi.com/2218-273X/10/1/101/s1, Figure S1: MALDI-TOF mass profile of $\mathrm{CPP}_{\mathrm{AIF}}$; Figure S2: MALDI-TOF mass profile of $\mathrm{CPP}_{\mathrm{AIF}}$ in water under different temperature for 1, 3 and 7 days; Figure S3: The HPLC chromatograms for cysteine and lysine depletion quantification of $\mathrm{CPP}_{\mathrm{AIF}}$; Figure S4: HPLC chromatogram of $\mathrm{CPP}_{\mathrm{AIF}}$ in different formulations applied in reconstructed human epidermis tissue model; Figure S5: Cytotoxicity test of CPP AIF to HaCaT cells; Table S1: $\mathrm{O} / \mathrm{W}$ formulation content

Author Contributions: Conceptualization, H.-M.L., M.D.-T.C.; Methodology, T.-K.F., P.-H.K., L.H.-C.W. and H.-M.L.; Resources, H.-M.L. and M.D.-T.C.; Experiments were carried out by P.-H.K., Y.-C.L., H.-N.L., Y.-C.L. and Y.-C.K.; Writing—original draft preparation, T.-K.F.; writing—review and editing, T.-K.F., L.H.-C.W., H.-M.L. and M.D.-T.C.; Funding acquisition, project administration and supervision, H.-M.L. and M.D.-T.C.; All authors have read and agreed to the published version of the manuscript.

Funding: This research was funded by Ministry of Science and Technology (MOST) grant MOST 107-0210-01-19-04, Industrial Value Creation Program for Academia (108B7016V1), Program for Translational Innovation of Biopharmaceutical Development-Technology Supporting Platform Axis (AS-KPQ-108-TSPA) and MOST grant Academia-Industry Collaboration by Research Institute (H456GB1530 \& H456GB1550).

Conflicts of Interest: The authors declare no conflict of interest.

\section{References}

1. Fields, K.; Falla, T.J.; Rodan, K.; Bush, L. Bioactive peptides: Signaling the future. J. Cosmet. Dermatol. 2009, 8, 8-13. [CrossRef] [PubMed]

2. Pai, V.V.; Bhandari, P.; Shukla, P. Topical peptides as cosmeceuticals. Indian J. Dermatol. Venereol. Leprol. 2017, 83, 9-18. [CrossRef] [PubMed]

3. Pickart, L.; Thaler, M.M. Tripeptide in human serum which prolongs survival of normal liver cells and stimulates growth in neoplastic liver. Nat. New Biol. 1973, 243, 85-87. [PubMed]

4. Bos, J.D.; Meinardi, M.M. The 500 Dalton rule for the skin penetration of chemical compounds and drugs. Exp. Dermatol. 2000, 9, 165-169. [CrossRef] [PubMed]

5. Gorouhi, F.; Maibach, H.I. Role of topical peptides in preventing or treating aged skin. Int. J. Cosmet. Sci. 2009, 31, 327-345. [CrossRef] [PubMed]

6. Lee, S.B.; Kim, Y.H.; Chong, M.S.; Hong, S.H.; Lee, Y.M. Study of gelatin-containing artificial skin V: Fabrication of gelatin scaffolds using a salt-leaching method. Biomaterials 2005, 26, 1961-1968. [CrossRef]

7. Sun, T.; Jackson, S.; Haycock, J.W.; MacNeil, S. Culture of skin cells in 3D rather than 2D improves their ability to survive exposure to cytotoxic agents. J. Biotechnol. 2006, 122, 372-381. [CrossRef]

8. Netzlaff, F.; Lehr, C.M.; Wertz, P.W.; Schaefer, U.F. The human epidermis models EpiSkin, SkinEthic and EpiDerm: An evaluation of morphology and their suitability for testing phototoxicity, irritancy, corrosivity, and substance transport. Eur. J. Pharm. Biopharm. 2005, 60, 167-178. [CrossRef] 
9. Mazlyzam, A.L.; Aminuddin, B.S.; Fuzina, N.H.; Norhayati, M.M.; Fauziah, O.; Isa, M.R.; Saim, L.; Ruszymah, B.H. Reconstruction of living bilayer human skin equivalent utilizing human fibrin as a scaffold. Burns 2007, 33, 355-363. [CrossRef]

10. Lopes, L.B.; Brophy, C.M.; Furnish, E.; Flynn, C.R.; Sparks, O.; Komalavilas, P.; Joshi, L.; Panitch, A.; Bentley, M.V. Comparative study of the skin penetration of protein transduction domains and a conjugated peptide. Pharm. Res. 2005, 22, 750-757. [CrossRef]

11. Degim, I.T. New tools and approaches for predicting skin permeability. Drug Discov. Today 2006, 11, 517-523. [CrossRef] [PubMed]

12. Fu, L.S.; Tsai, J.J.; Chen, Y.J.; Lin, H.K.; Tsai, M.C.; Chang, M.D. Heparin protects BALB/c mice from mite-induced airway allergic inflammation. Int. J. Immunopathol. Pharmacol. 2013, 26, 349-359. [CrossRef] [PubMed]

13. Chen, K.W.; Fuchs, G.; Sonneck, K.; Gieras, A.; Swoboda, I.; Douladiris, N.; Linhart, B.; Jankovic, M.; Pavkov, T.; Keller, W.; et al. Reduction of the in vivo allergenicity of Der p 2, the major house-dust mite allergen, by genetic engineering. Mol. Immunol. 2008, 45, 2486-2498. [CrossRef] [PubMed]

14. Park, J.; Ryu, J.; Kim, K.A.; Lee, H.J.; Bahn, J.H.; Han, K.; Choi, E.Y.; Lee, K.S.; Kwon, H.Y.; Choi, S.Y. Mutational analysis of a human immunodeficiency virus type 1 Tat protein transduction domain which is required for delivery of an exogenous protein into mammalian cells. J. Gen. Virol. 2002, 83, 1173-1181. [CrossRef]

15. Chang, M.; Chou, J.C.; Lee, H.J. Cellular internalization of fluorescent proteins via arginine-rich intracellular delivery peptide in plant cells. Plant. Cell Physiol. 2005, 46, 482-488. [CrossRef]

16. Siprashvili, Z.; Reuter, J.A.; Khavari, P.A. Intracellular delivery of functional proteins via decoration with transporter peptides. Mol. Ther. 2004, 9, 721-728. [CrossRef]

17. Lim, J.M.; Chang, M.Y.; Park, S.G.; Kang, N.G.; Song, Y.S.; Lee, Y.H.; Yoo, Y.C.; Cho, W.G.; Choi, S.Y.; Kang, S.H. Penetration enhancement in mouse skin and lipolysis in adipocytes by TAT-GKH, a new cosmetic ingredient. J. Cosmet. Sci. 2003, 54, 483-491.

18. Schutze-Redelmeier, M.P.; Kong, S.; Bally, M.B.; Dutz, J.P. Antennapedia transduction sequence promotes anti tumour immunity to epicutaneously administered CTL epitopes. Vaccine 2004, 22, 1985-1991. [CrossRef]

19. Rothbard, J.B.; Garlington, S.; Lin, Q.; Kirschberg, T.; Kreider, E.; McGrane, P.L.; Wender, P.A.; Khavari, P.A. Conjugation of arginine oligomers to cyclosporin A facilitates topical delivery and inhibition of inflammation. Nat. Med. 2000, 6, 1253-1257. [CrossRef]

20. Fang, S.L.; Fan, T.C.; Fu, H.W.; Chen, C.J.; Hwang, C.S.; Hung, T.J.; Lin, L.Y.; Chang, M.D. A novel cell-penetrating peptide derived from human eosinophil cationic protein. PLoS ONE 2013, 8, e57318. [CrossRef]

21. Chen, C.J.; Tsai, K.C.; Kuo, P.H.; Chang, P.L.; Wang, W.C.; Chuang, Y.J.; Chang, M.D. A Heparan Sulfate-Binding Cell Penetrating Peptide for Tumor Targeting and Migration Inhibition. Biomed. Res. Int. 2015, 2015, 237969. [CrossRef]

22. Lee, C.W.; Kim, S.C.; Kwak, T.W.; Lee, J.R.; Jo, M.J.; Ahn, Y.T.; Kim, J.M.; An, W.G. Anti-inflammatory effects of bangpungtongsung-san, a traditional herbal prescription. Evid. Based Complemen. Altern. Med. 2012, 2012, 892943. [CrossRef] [PubMed]

23. Bartosh, T.J.; Ylostalo, J.H. Macrophage Inflammatory Assay. Biol. Protoc. 2014, 4. [CrossRef] [PubMed]

24. Vaure, C.; Liu, Y. A comparative review of toll-like receptor 4 expression and functionality in different animal species. Front. Immunol. 2014, 5, 316. [CrossRef] [PubMed]

25. Yamada, P.; Iijima, R.; Han, J.; Shigemori, H.; Yokota, S.; Isoda, H. Inhibitory effect of acteoside isolated from Cistanche tubulosa on chemical mediator release and inflammatory cytokine production by RBL-2H3 and KU812 cells. Planta Med. 2010, 76, 1512-1518. [CrossRef]

26. Suschek, C.V.; Bruch-Gerharz, D.; Kleinert, H.; Forstermann, U.; Kolb-Bachofen, V. Ultraviolet A1 radiation induces nitric oxide synthase-2 expression in human skin endothelial cells in the absence of proinflammatory cytokines. J. Investig. Dermatol. 2001, 117, 1200-1205. [CrossRef]

27. Bashir, M.M.; Sharma, M.R.; Werth, V.P. UVB and proinflammatory cytokines synergistically activate TNF-alpha production in keratinocytes through enhanced gene transcription. J. Investig. Dermatol. 2009, 129, 994-1001. [CrossRef]

28. Mazza, J.; Rossi, A.; Weinberg, J.M. Innovative uses of tumor necrosis factor alpha inhibitors. Dermatol. Clin. 2010, 28, 559-575. [CrossRef] 
29. Pinho, B.R.; Sousa, C.; Valentao, P.; Oliveira, J.M.; Andrade, P.B. Modulation of basophils' degranulation and allergy-related enzymes by monomeric and dimeric naphthoquinones. PLoS ONE 2014, 9, e90122. [CrossRef]

30. Tan, J.; Cheong, H.; Park, Y.S.; Kim, H.; Zhang, M.; Moon, C.; Huang, Y. Cell-penetrating peptide-mediated topical delivery of biomacromolecular drugs. Curr. Pharm. Biotechnol. 2014, 15, 231-239. [CrossRef]

(C) 2020 by the authors. Licensee MDPI, Basel, Switzerland. This article is an open access article distributed under the terms and conditions of the Creative Commons Attribution (CC BY) license (http://creativecommons.org/licenses/by/4.0/). 